\title{
構造物の累積損傷抑制設計に関する研究 STUDY ON DESIGN FOR CONTROL OF CUMULATIVE DAMAGE IN STRUCTURES
}

\author{
内田保博* \\ Yasuhiro UCHIDA
}

\begin{abstract}
A method of design is presented for the purpose of controlling the cumulative damage such as the strength deterioration and the accumulation of deformation in structures subjected to repeated loading. In the presented method of design, the limitation of the constant force acting on the beam-column and the beam is incorporated into the current method of design, and its limiting values can be derived from the critical force for convergence of the accumulation of deformation proposed by the author. The concept of design also presented is that the separation of a portion subjected to the constant force in a structure from that subjected to repeated loading is effective for preventing an increase in accumulation of the deformation. Examples of design for bracing structures, reinforced concrete walls and the steel beam-columns give a concrete form for the concept of design. The validity of the presented method of design and its examples are discussed with analytical results of beam-columns and truss structures.
\end{abstract}

Keywords: cumulative damage, constant force, convergence of accumulation, beam-column, truss structure, elastic-plastic analysis, method of design

累皘損傷、一定外力、累積の収束、柱、トラス構造、弾塑性解析、設計法

\section{1. 序}

構造物が大地震時及び暴風時におけるように大きな繰 返し外力を受けるとき、耐力低下を生じることが予想さ れる。そこで大きな繰返し外力に対し安全な構造物を設 計するためには、繰返し外力による耐力低下及び変形の 累皘等の累積損傷を抑制する必要がある。構造物が繰返 し外力を受けるとき損傷の累積が生じ、累積の量がある 限界に達すると構造物は崩壊する。鋼構造、鉄筋コンク リート構造、鉄骨鉄筋コンクリート構造の累積損傷及び 崩壊過程について多くの研究がなされてきたが、繰返し 外力を受ける構造物及び部材の安定性に関しては、次の

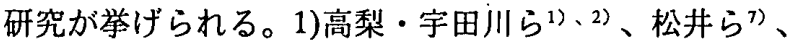
平石ら ${ }^{8)}$ は、繰返し載荷を受ける鉄骨はり、鉄骨鉄筋コ ンクリート柱及び鉄筋コンクリート柱の履歴曲線が定常 化する安定限界について調べている。2)上谷ら ${ }^{3) 、 4) ~}$ は、定振幅繰返し荷重を受ける構造物及び部材の変形累 積経路に分岐現象が生じる限界としての対称限界、及び 非対称定常状態経路の限界としての定常状態限界を示し
ている。3)近藤ら5、6)は、繰返し変動荷重を受ける棈 造物のShake Down 後の応答領域と荷重の変動領域の関 係を組織的に追跡しうる解析手法の開発をしている。

繰返し荷重を受ける構造物及び部材の性能を向上させ る設計については、各種構造において個々に様々な提案 がなされているが、繰返し荷重を受ける構造物及び部材 の損傷に関する理論に基づいた設計法については、加

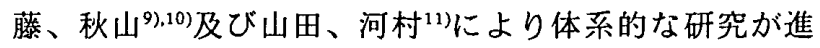
められてきた。

構造物には自重や積載荷重等の一定鉛直力が作用して おり、これにより構造物の柱及びはりに一定軸力や一定 曲げモーメントが作用する。本研究ではこれらの力を構 造物又は部材に作用する一定外力と定義する。構造物が 繰返し水平力等の繰返し外力及び一定外力を受けると き、一定外力に対応した変形に累積現象が生じる。ここ に一定外力とは作用させた力を意味し、繰返し外力と は、変位又は変形を作用させるときの力、すなわち変位 制御で与えた力を意味している。なお繰返し外力が荷重

$*$ 鹿児島大学工学部建築学科 助教授 $\cdot$ 工博

Assoc. Prof., Dept. of Architecture, Faculty of Engineering, Kagoshima Univ., Dr. Eng. 
制御で与えられれば、一定外力のみでなく繰返し外力に 対応した変形にも累積現象が生じる。一定外力の大きさ は変形累積挙動に大きな影響を与えるが、上記の研究に おいてこの観点から累積損傷は十分には調べられておら ず、また累積損傷を抑制する構造及び設計法についても 示されていない。

筆者らは、従来下記の1) 4)の事項について調べてき た。

1)局部座屈により耐力低下を生じる角形鋼管柱の耐力低 下挙動及び変形の累積挙動が収束するか発散するかは、 一定軸力の大きさに依存することを調べた ${ }^{12)}$ 〜3)。また さらにこれを一般化し、定変位振幅繰返し外力を受ける 構造物に耐力低下が生じるか否かに拘らず、一定外力の 大きさに応じて、変形の累積に収束・発散現象が存在す ることを仮説として提案した ${ }^{15)}$ 。ここに変形累積の収束 とは、変形が同じ累積経路上で挙動し定常化することを 表し、変形累積の発散とは、変形累積が収束することな く進行し続けることを意味している。

2)変形の累積現象之耐力低下挙動は密接に関係すること を明かにし、この仮説に基づき構造物の耐震安全性確保 及び部材の䩰性確保を目的とした一定外力比制限が可能 であることを示した。ここに一定外力比とは、一定外力 と構造物の規準耐力の比として定義される。

3)定変位振幅繰返し荷重を受け耐力低下を生じる鋼柱、 鉄骨鉄筋コンクリート柱、トラス構造の変形累積が収束 する限界時及び崩壊限界時の一定軸力や一定鉛直力を求 め、各々を一定外力比制限の下限值及び上限值とするこ 亡ができることを示し、収束限界時及び崩壊限界時の一 定外力を用いて繰返し加力時の变形累積や耐力低下挙動 を予測することが可能であることを明らかにした ${ }^{14 \sim 17) 。 ~}$ 4)収束限界軸力及び崩壊限界軸力を理論的に導きその一 般的特性を示すとともに ${ }^{18)}$ 、2次仕事を用いた変形累皘 の安定性の判定方法を示した ${ }^{199}$ 。

本研究では今までに得られた知見をもとに、耐力低 下及び変形累皘等の累積損傷を抑制するための構造物の 設計法について提案するとともに設計例を示す。また計 算により得られたブレース構造及び柱のモデルの一定外 力比制限値及び変形の累積挙動に照らして設計法及び設 計例の妥当性を検討する。

\section{2. 累積損傷を抑制する設計}

\section{1 設計手順}

建物の構造設計は、通常図-1の(1) (3)の手順で行われ る。従来筆者らは、構造物や部材の耐力低下及び変形累 積を抑制するために、自重や積載荷重などの常時荷重に より生じる柱軸力比及びはりの鉛直力と構造物の基準耐 力に対する比などの一定外力比が制限值以下になるよう

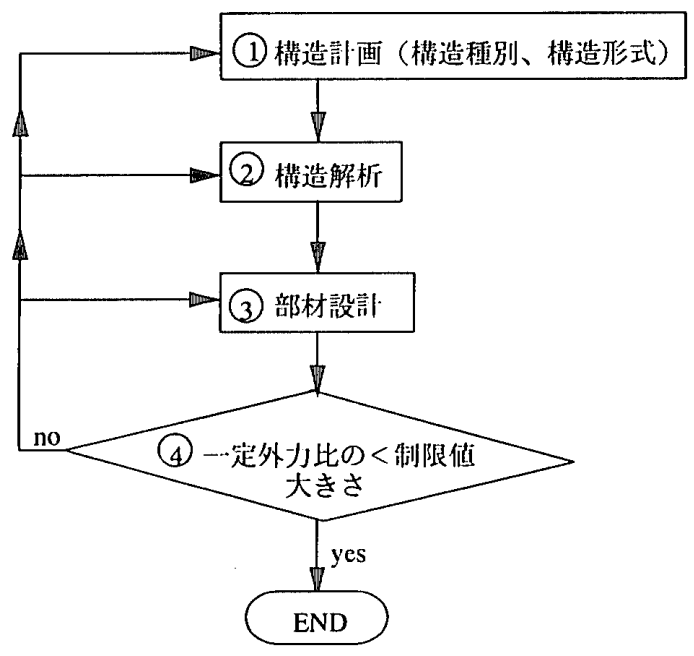

図-1 構造設計手順

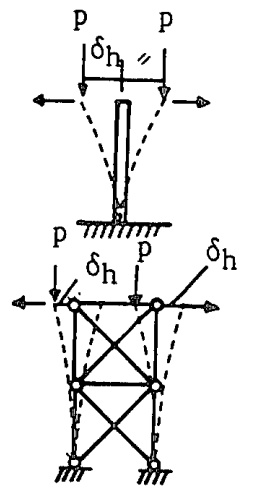

(a)繰返し力を受ける柱 及び構造物

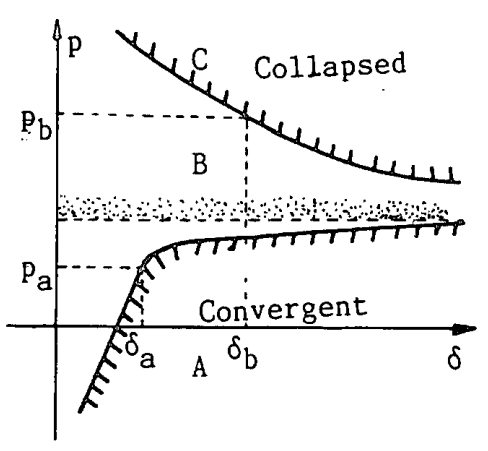

(b)収束限界外力曲線及び 崩壊限界外力曲線

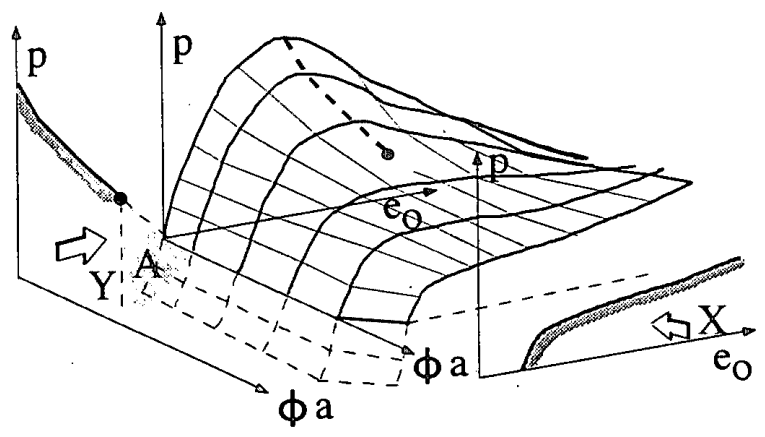

(c)柱の収束限界軸力曲面

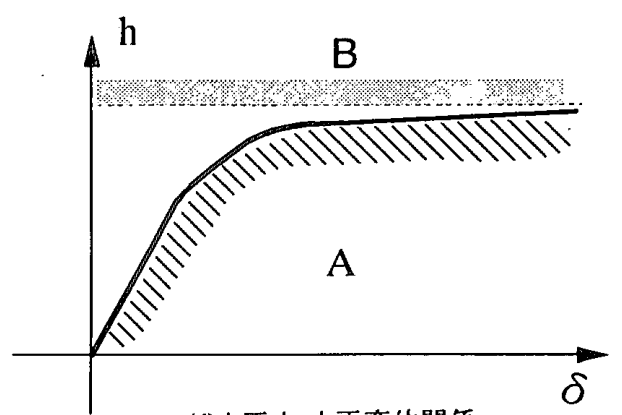

(d)水平力-水平変位関係

图-2 累積損傷抑制設計に用いる収束限界外力曲線 


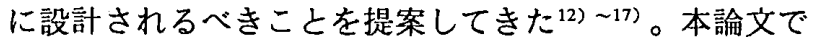
はこの提案に基づきさらに、図-1の構造計算の流れ図の 中に、新たに(4)の設計手順を組み込むことを提案する。 構造計算の流れ図の中で、(4)の判定条件を満足しなけれ ば、(1)又は(3)へ戻り(4)の判定条件を満足するまで設計を やり直すことになる。(1)又は(3)においては、繰り返し加 力時の耐力低下及び変形の累積を抑えるために又は塑性 ヒンジ等の鞄性確保を目的とし、後述の設計事項等を考 虑して構造形態、構造種別の組合せ、断面設計における 要素材料の選択及び配置の工夫をする。ここに(4)におけ る判定の規準值として用いられる一定外力比の制限值 は、構造物の寸法、材料の機械的性質等により決定さ れ、構造物の設計が一応終了する(3)の最後で得られる量 であり、反復計算過程において一定外力比とともに変化 する量である。設計で用いられるべき一定外力比の制限 值を提案するまでに未だ至っていないが、定変位振幅繰 り返し外力の下で得られる収束限界外力比を一定外力比 制限の下限值及び崩壊限界外力比を上限値として良いこ とを示している14)。

\section{2 収束限界及び崩壊限界外力曲線}

収束限界外力及び崩壊限界外力を図-2(b)に示す。図2(a)に示す柱や構造物に一定外力 $p$ 及び定変位振幅繰返 し水平力 $h$ が作用するとき、一定外力に対応する変形の 累積がある変位 $\delta$ ，で収束する限界時の一定外力 $p$ ，を収 束限界外力と定義する。すなわち $p$ が $p$ 。以下では変形の

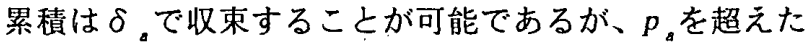

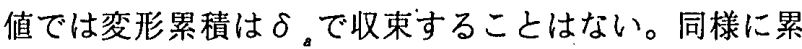
積変位が $\delta_{b}$ に達したとき崩壊する限界時の一定外力 $p_{b}$ を崩壊限界外力と定義する。図中のAで示される領域で は変形の累積は収束するが、Bの領域では変形の累積は 増大する。Cは崩壊領域である。収束限界外力及び崩壊 限界外力は、これに対応する変形及び曲率振幅等のパラ メータを用いて曲線で表され、これを収束限界外力曲線 及び崩壊限界外力曲線と称する ${ }^{18)}$ 。図-2(c)中の曲面は、 一定軸力と定曲率振幅繰返し曲げを受ける柱のひずみの 累積が、軸力p、重心ひずみ $e_{0}$ 及び曲率振幅 $\phi$ 。空間に おいて収束する領域を示す。任意の $\phi$ 。位置での $e_{0}$ 軸方 向の横断面である $p-e_{0}$ 関係をX方向から見た図が収束限 界軸力曲線である。またY方向から収束する領域を見た とき、収束限界軸力 $\mathrm{p}$ の最大值の点を結んだ曲線として $p$ - $\phi$ 曲線を表すことができる。ただし $p-e_{0}$ 関係が常に正 勾配で上昇するA領域では $p-\phi_{\mathrm{a}}$ 曲線は存在しない。

1 方向加力時の骨組の水平荷重 $h-$ 変位 $\delta$ 関係は、図2(d)の実線で表される。繰返し加力時と同様、A領域は 力の釣合いが成立する領域であり骨組は安定であるが、 B領域では力の釣合いが成立せず変形が動的に増大す る。骨組の耐力に基つく設計では、図-2(d)に示す荷重一 変形関係が基礎になるが、骨組の変形累積、耐力低下等 の累積損甥抑制を目的とした設計では、図-2(b)に示す収 束限界外力曲線を基礎として良いと考えられる。

\section{3 一定外力比制限と定变位振幅}

一定外力の収束限界及び制限値は、定変位振幅（図3(a)参照）の繰り返し荷重の下で導かれる。図-3中の $\delta$ は等えられる繰返し変位、cycle は繰り返し回数であ る。図-3(b)、(c)に示す変位の繰返しパターンを伴う荷 重を樍造物が受けるとき、繰返しパターンの違いにより 収束限界は変化するが、これらの収束限界值は各定変位 振幅に対する限界值から概称予测できる。また地震力が 構造物に作用するとき、数サイクルの大きな非定常状態 の力が問題となり、定常状態の繰り返し外力の下で数十 サイクル後に履歴曲線が収束するか否かの問題と耐震性 能評価の問題と直接結びつかないように思えるが、材料 試験等で行われているように明確な一定の評価規準を設 け、規則性がある負荷を与えたときの耐震性能は、真の 耐震性能をある程度表しているし、性能評価をする上で の目安になると考えられる。また地震時の耐力低下や塑 性変形は、一般に主要な数サイクルの繰返しにより大き く生じるが、収束・崩壊限界外力曲線からこれらの挙動 は概ね予測できる。

\section{4 一定外力比制限及び定変位振幅制限}

本研究では、図-4(a)に示すように定変位振幅 $\delta_{h r}$ の 繰り返し外力を与えたときの一定外力比pの制限を行な い変位レベル一定下での規準を用いる方法を提案す る。図-4中の $p_{c r} 、 \delta_{c r}$ は各々 $p$ 及び $\delta_{h r}$ の制限值である。

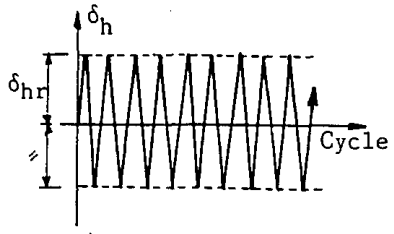

(a)

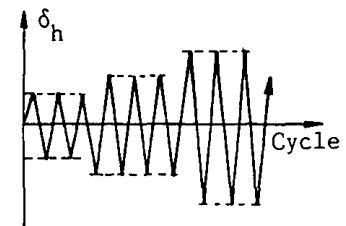

(b)

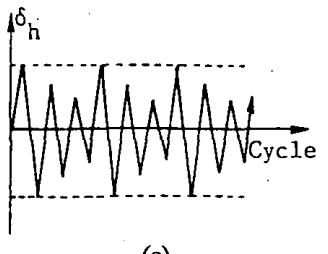

(c)

図 -3 桨位履歴

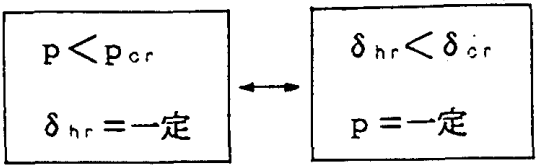

(a)

(b)

因-4 一定外力比制限及び定贸位振幅制限 
一方図-4(b)に示すように一定外力比の大きさを不変とす る外カレベル一定下で、耐力低下が顕著となる限界点又 は変形累積が急増する安定限界点における変位振幅 $\delta_{b r}$ が制限值以下になるように設計する方法も考えられる。 しかし変位レベル一定下で一定外力比制限を行う方法の 方が、フィードバックし断面サイズ等を変更して一定外 力比制限值を変えることにより、一定外力比の判定条件 を満足するように設計することが容易であり、設計にお いては利便性を有していると考えられる。

定変位振幅繰り返し加力の下で一定外力比制限を行う とき、定変位振幅の大きさの設定には、地震力等の繰り 返し外力を受ける構造物の応答評価の問題と関わってい る。従って一定外力比制限を行うとき、例えば使用限界 時及び終局限界時の定変位振幅の大きさを個別に定めた り、許容できる累積変形量を設定することが必要であ る。

\section{5 累積損傷抑制のための設計事項}

構造計画及び部材設計において、耐力低下及び変形の 累積を抑制するために考虑しなければならない設計事項 として以下の事項が考えられる。

(1)構造物の収束限界外力及び崩壊限界外力が大きくな るように、部材及び断面内要素を配置するとともに力学 的特性の選択をする。

(2)初期外力の導入

(3)変形累皘収束時の破壊抑制のための一定外力比の 設定

(1)の事項の詳細は3、(2)及び(3)の事項の詳細は4.にお いて述べられる。

\section{3. 累積損傷を抑制するための部材及び断面内要素の 配置及び力学的特性の選択}

\section{1 設計理念}

構造物の耐力低下及び変形の累積を抑えるためには、

『構造物又は部材に一定外力と繰り返し外力が作用する とき、一定外力に主に抵抗する構造部分と主に繰り返し 外力に抵抗する構造部分とを分離して設計する』必要が あると考えられる。これは、もし一定外力と繰り返し外 力に抵抗する構造部分が同一であれば、構造部分に耐力 低下が生じたとき、一定外力を保持するために変形の累 積が生じ、耐力低下をさらに引き起こし易いからであ る。「一定外力に主に抵抗する構造部分の耐力を大きく し、耐力低下が生じないようにする」ことも重要であ る。もし一定外力に主に抵抗する部分の耐力低下が大き いことが予想されるとき、繰り返し外力を主に受ける構 造部分の耐力を一定外力を主に受ける部分に比へて相対 的に小さくする必要がある。これは、繰返し外力を主に 負担する構造部分の耐力を小さくすれば、変形の累積が
生じないと仮定したとき繰返し加力に伴い発生する、繰 返し外力を受ける部分の不釣合い力を減少させることが できるので、この不釣合い力を解消させる役目を持つ一 定外力を主に受ける部分の負担を小さくすることができ るためである。

\section{2 設計例}

3.1の設計理念を形に表した例を図-5(a)〜 (f)に示す。 柱及びはり材が各々軸力、曲げ、せん断全てに抵抗する 剛節骨組ではなく、主に一定鉊直力に抵抗する部分と水

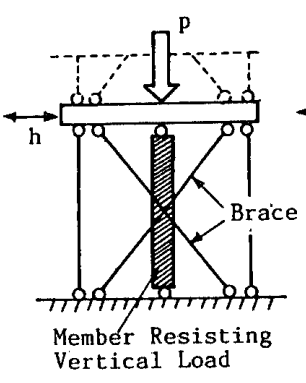

(a)

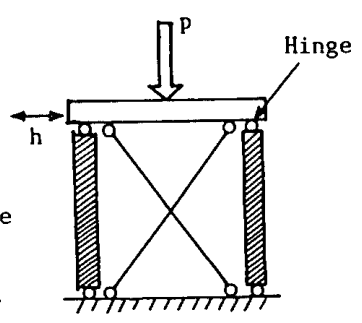

(b)

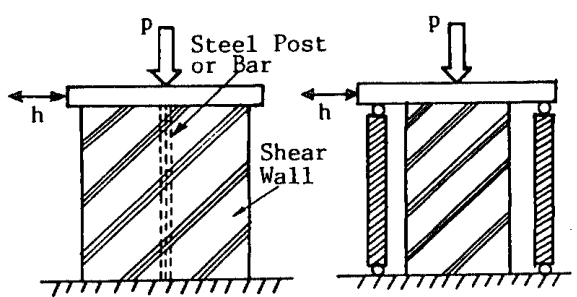

(c)

(d)

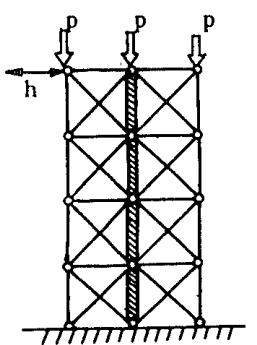

(e)

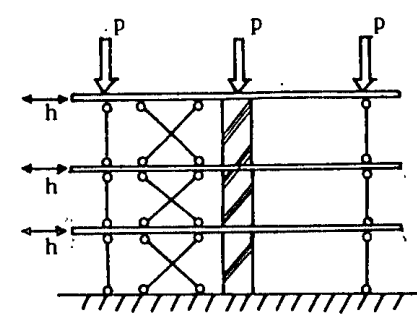

(f)

因-5 構造物の累積損倁抑制設計例

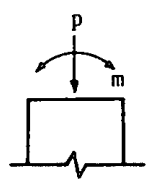

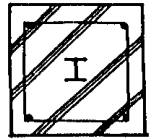

(a)

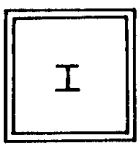

(b)

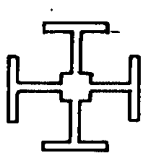

(c)

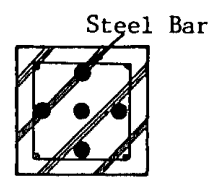

(d)

図-6 部材断面の累積損甥抑制設計例 
平力に抵抗する部分とを切り離した設計例を示してい る。図-5(a) (d)において、一層一スパン構造の例及び 同(e),(f)に多層多スパン構造の例を示している。図中pは 一定外力を表し、hは繰返し外力を表す。また一定軸力 と繰り返し曲げが作用する部材断面についても、図-6に 示すように一定外力である軸力 $p$ のみ負担する芯部分之 繰返し外力である曲げモーメントmを負担する周囲の部 分に分けて断面設計を行うと、重心ひずみの累積が小さ いことが予想される。図-6(a)は、角形鋼管の中に芯鉄骨 を入れた柱断面である。この場合断面中央に面積が集中 しかつ強度が高い芯鉄骨を入れておけば、角形鋼管の幅 厚比が大きくても、繰り返し外力による耐力低下の進行 は遅いと予想される。また図-6(c)に示す鉄骨断面のウェ ブの交点の鉄骨量を多くして、ここで軸力を主に抵抗さ せるときも同様の効果がある。図-6(d)に示すようにSRC 断面内に鉄骨を配置すると、一定軸力及び一定曲げ並び に直交軸回りに繰り返し曲げを受けるときの累積損傷抑 制に効果があると考えられる16)。なお一定外力を主に負 担する要素のサイズは、次に述べるように、変形累積の 抑制や最大耐力を考虑して適切に定めなければならな io

\section{3 柱の累積損傷抑制設計法の検討}

次に3.2で述べた設計法の妥当性について明らかにす るため、図-7に示す鋼柱3要素断面モデルが、一定軸力 とx軸回り定曲率振幅繰返し曲げを受けるとき、耐力低 下及び変形の累積を抑制する条件を導く。仮定した各要 素の軸方向応力度一ひずみ度関係を図-8に示す。正縮側 の符号を負とし、局部座屈による鋼材の耐力低下を巨視 的にとらえて、応力度ひずみ度関係を劣化型と仮定し た。応力 $s$, ひずみ $e$ 降伏時の量で無次元化されてい る。図-9には、降伏時の量で無次元化されたx軸回り曲 率 $\phi$ の履歴を示す。

文献17)において、変形累皘収束限界時の一定外力す なわち収束限界外力に関する定理を下記の通り提案して いる。

「収束変位 $\left\{\delta_{i}\right\}$ を有する収束限界状態から変位增分 $\left\{\Delta \delta_{i}\right\}$ を比例的に与えながら、定振幅繰返し变位を構 造体に与えたときに得られる $\left\{\delta_{i}\right\}+\left\{\Delta \delta_{i}\right\}$ に対応 する外力の最小值は収束限界外力と一致し、 $\left\{\delta_{i}\right\}+$ $\left\{\Delta \delta_{\mathrm{i}}\right\}$ の最大值は、累皘変位の収束值の最大值であ る。』

この定理によると、図-7に示す3要素断面モテルの収 束限界軸力は、ある値の一定重心ひずみを与えて定曲率 振幅繰返し曲げを加えたとき、変動する軸力 $p$ の最小值 として与えられる。本計算例では、曲率反転点において $p$ は最小值をとるので、収束限界軸力 $p$ 及び収束時曲げ モーメントmは(1)式で与えられる。変形累積が収束する とき、1,3質点の応力-ひずみ関係上の履歴を図-8に太線
で示し、ある曲率反転点における質点 1,3 の応力 $s_{1}, s_{3}$ を同 図中に記入している。なお $s_{1}, s_{3} に$ 対応するひずみ $e_{1}, e_{3}$ は、各々 $e_{0}-d_{1} \phi_{r} e_{0}+d_{3} \phi_{r}$ で与えられる。(1)式における pは降伏時の量で無次元化された軸力であり、曲げモー メントmは $A \cdot d \cdot \sigma_{y}$ で無次元化されている。ここに $A$ は全断面皘、dは1、3要素と断面の重心間距離、 $\sigma_{y}$ は降 伏応力である。

$$
p=\sum_{i=1}^{3} a_{i} s_{i} 、 m=\sum_{i=1}^{3} a_{i} \cdot d_{i} \cdot s_{i} .
$$

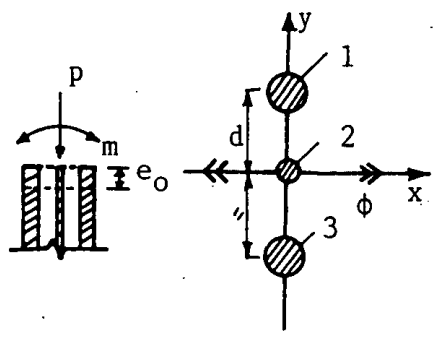

因-7 3要素モデル

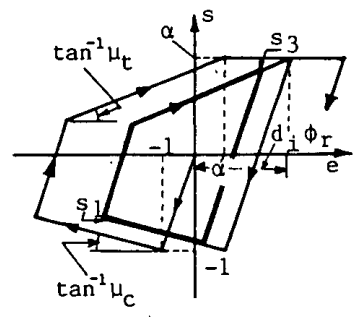

図-8 応力度ひずみ度 関係

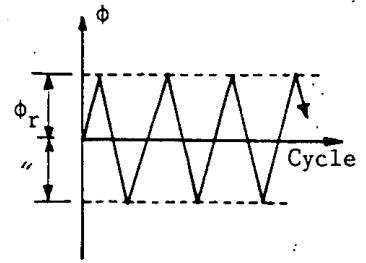

因-9 明率履歷

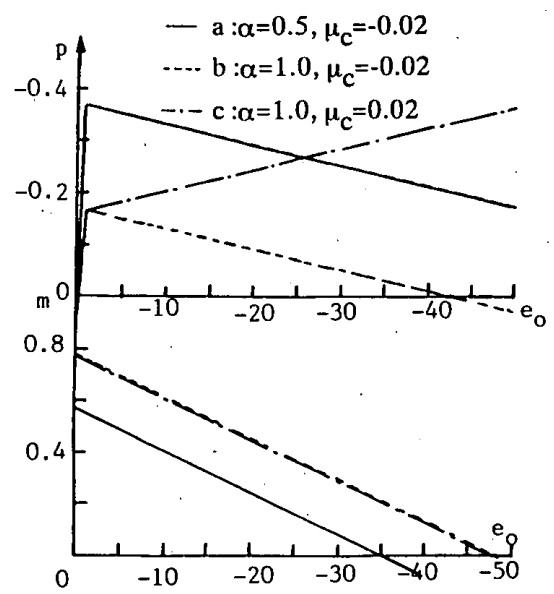

図-10 耐震設計と収束限界軸力関係

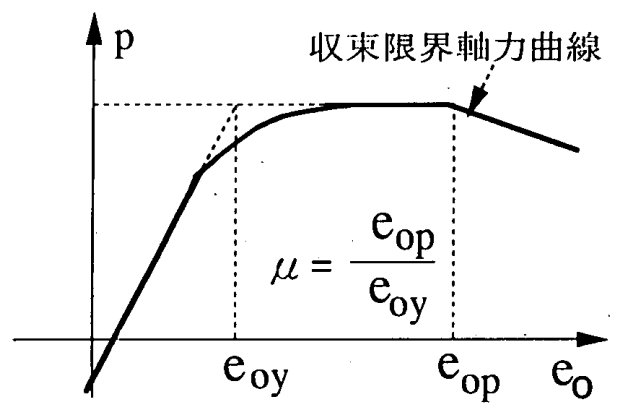

因-11 繰返し載荷時の変形能力の評価 


$$
\begin{aligned}
& s_{1}=\mu_{c 1}\left(e_{o}-2 d_{1} \phi_{r}+1+\alpha\right)-1 \\
& s_{3}=\mu_{t 3} e_{o}+\alpha \\
& s_{2}=\left\{\begin{array}{cc}
e_{o} & \left(e_{o} \geq-1\right) \\
\mu_{c 2}\left(e_{o}+1\right)-1 & \left(e_{o}<-1\right)
\end{array}\right.
\end{aligned}
$$

ここに、 $a_{i}=\mathrm{i}$ 要素の断面皘、 $d_{i}=\mathrm{i}$ 要素の重心位置の座 標、 $d_{1}=d_{3}=d=1 、 d_{2}=0$

$\mu_{c i} 、 \mu_{t i}=\mathrm{i}$ 要素の区縮側及び引張り侧塑性域の勾 配、 $s_{i}=\mathrm{i}$ 要素の応力、 $e_{o}=$ 重心ひずみ

(1)式から得られた収束限界軸力曲線及び累積収束時の 曲げモーメントー重心ひずみ関係の計算例a，b，cを図10に示す。e $e_{0}$ は、図-7に示す重心ひずみである。応力度 ーひずみ度関係の圧縮側塑性域の勾配 $\mu_{c}=-0.02$ 及び引 張り侧塑性域の勾配 $\mu_{t}=0.02$ とし、全断面皘で無次元化 された1、3要素の断面積 $a_{1}=a_{3}=0.4 、 2$ 要素の断面積 $a_{2}$ $=0.2$ とした。また曲線 $\mathrm{a}$ のースでは、引張り側降伏応

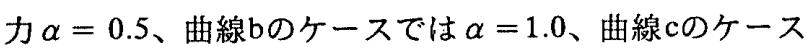
では $\alpha=1.0 、 2$ 要素の $\mu_{c}=0.02$ とした。 $\alpha$ 值は通常 1.0であるが、後述するスライダー等により $\alpha$ の值が調

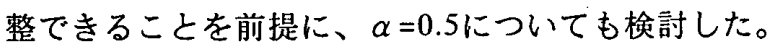

曲線aのケースでは、収束限界軸力は大きいが、収束 時の曲げ耐力は小さい。一方曲線bのケースでは、収束 限界軸力比の大きさは全般に小さいが、収束時の曲げ耐 力は曲線aのケースに比べきい。a，b何れのケースも 各々得失があり、耐力低下、変形累積、曲げ耐力の観点 からa，b何れのケースの耐震性能が優れているかを総合 的に判断する問題は、今後の課題としたい。曲線cの ケースでは、収束限界軸力曲線は正勾配を持っており、 曲線bのケースと比べると曲げ耐力は同じであるが変形 の累積が小さいことが分かり、明らかにbのケースに比 へ耐震性能は優れている。これら 視点から分類すると以下の様になる。

1)変形能力が要求されない部材、構造物に対してはbの タイプで設計すればよい。

2)鞄性がなく十分な変形能力が期待できないケースで累 積損傷を生じさせたくないときは、耐力を大きくとるよ うにしてaのタイプで設計すれば良い。

3)勒性設計が可能なときは、cのタイプで設計ができ る。

なお上記の計算例では応力-ひずみ関係をBi-Linear型 としたため収束限界軸力曲線もBi-linear型となっている が、一般に収束限界軸力曲線は図-11の様に表される。 収束限界軸力低下時の重心ひずみ $e_{o p}$ 及び最大収束限界軸 力に対応するひずみ $e_{o y}$ から計算される $\mu=e_{o p} / e_{o y}$ は、繰返 し力を受けたときの柱の変形能力を表しており、一方向 単調加力時の塑性率に相当するパラメータである。

\section{4 トラス構造物の累積損傷抑制設計の検討}

次に定変位振幅 $\delta_{h r}$ (図-13参照) の繰返し水平力を 受けるブレース及び床板を有する 1 層 1 スパンの棈造物

（図-12参照）を例にとり、図-5(a)〜(d)において示され る骨組の累積損傷抑制設計法の妥当性について調べる。 床板の重量は $w 、 \delta_{n}$ 及び $\delta_{v}$ は床板重心の水平変位及び 鉛直方向変位であり、 $\theta_{i}$ は部材の傾き、 $\ell$ は柱材の長さ である。柱材の部材番号iは1、4、5であり、ブレースの 部材番号は2、3である。各部材の両端はピン接合されて おり、床板は剛とする。柱材及びブレースの材料は鋼で あり、それらの軸方向応力度一ひずみ度関係を図-14に 示す。ブレース材の計算においては、曲げ座屈による耐 力低下を考慮して少化形の応力度一ひずみ度関係を仮定 した。図中、 $s_{i}, e_{i}$ は各部材の降伏時の量で基準化され た無次元応力、無次元ひずみである。

水平力が構造物の床板に加わるとき、水平変位及び鉛 直変位とともに構造物全体のモーメントが釣合う様に、

一般に床板の回転が生じる。しかし、ここでは構造物を せん断形にモデル化しており、床板には水平変位と鉊直 方向変位のみが生じるものとする。なお、引張り側の力 及び変位の符号を正とする。

図-12のモデルの鉛直方向及び水平方向の力の釣合式 は下記の通りとなる。

1)鈶直方向

$$
w=\sum_{i=1}^{5} s_{i}\left(e_{i}\right) \cdot A_{i} \cdot \sigma_{y i} \cdot \sin \theta_{i} / W_{y}
$$

2)水平方向

$$
h=\sum_{i=1}^{5} s_{i}\left(e_{i}\right) \cdot A_{i} \cdot \sigma_{y i} \cdot \cos \theta_{i} / W_{y}
$$

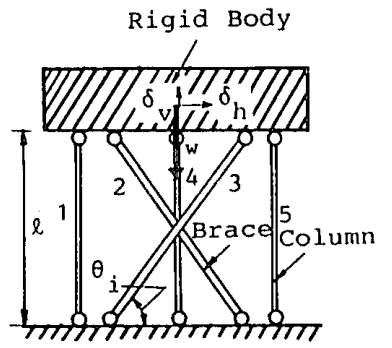

図-12 トラス構造

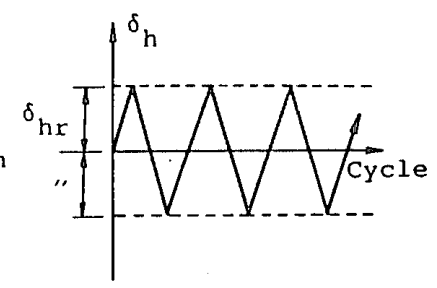

图-13 変位履歴

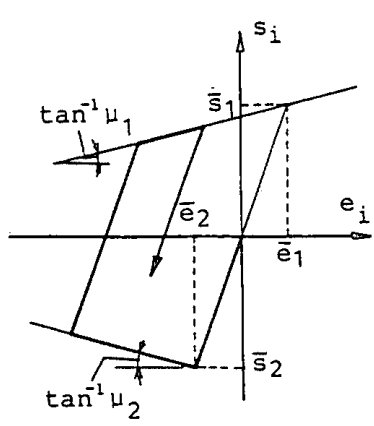

(a)ブレース

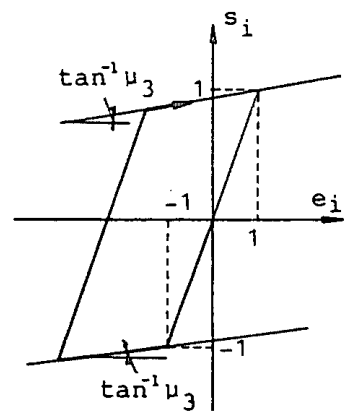

(b)柱
图-14 応力度-ひずみ度関係 
ここに $W_{\mathrm{y}}=\sum A_{\mathrm{i}} \sigma_{y_{i}} \sin \theta_{\mathrm{i}} 、 \mathrm{i}=$ 部材番号 $e_{i}=\left(\delta_{h} \cos \theta_{i}+\delta_{\nu} \sin \theta_{i}\right) \cdot \sin \theta_{i} /\left(\ell \cdot \varepsilon_{y i}\right)$

$A_{i}=$ 各部材の断面積

$\sigma_{y_{i}}="$ 降伏応力

$\varepsilon_{y_{i}}=" \quad$ 降伏ひずみ

$w=W_{y}$ で無次元化された床板荷重

$h="$ 水平荷重

$\delta$ 、の累積が収束したとき、左右各反転点において $\delta_{h}$ が $\delta_{h r} 、-\delta_{h r}$ であるときの各部材の応力 $s_{i}$ を図-15に

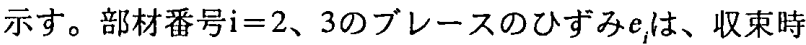
各々 $\delta_{v} \cdot \sin \theta_{i}{ }^{2} /\left(\ell \cdot \varepsilon_{\mathrm{yi}}\right)$ を中心にして $\delta_{h r} \cdot \cos \theta_{i} *$ $\sin \theta_{i} /\left(\ell \cdot \varepsilon_{y_{i}}\right)$ の振幅で変動する。また $\mathrm{i}=1 、 4 、 5$ の柱材のひずみ $e_{i}$ は $\delta{ }_{v} /\left(\ell \cdot \varepsilon_{y_{i}}\right)$ の值をとる。累皘 収束時 $\delta_{n}>0$ の反転点における鉛直方向の力の釣合式で ある(2)式から、累積の収束、発散領域を表す $w, \delta_{n} /$ $\ell 、 \delta 、 / \ell の$ 関係式が(4)式として得られる。ここに $s_{i}(\mathrm{i}=1,4,5)=\mu_{2}\left(e_{\mathrm{i}}+1\right)-1 、 s_{2}=\mu_{2}\left(e_{2}-\bar{e}_{2}\right)+\bar{s}_{2} 、 s_{3}=\mu_{2}\left(e_{3}-\right.$ $\left.\bar{e}_{1}\right)+\bar{s}_{1}$ である。また、 $\delta 、 の$ 累積が収束したときのブ レースのひずみ振幅は $\delta_{h_{r}} \cdot \cos \theta_{i} \cdot \sin \theta_{i} /\left(\ell \cdot \varepsilon_{y i}\right)$ $\geqq 1$ とし、柱材の変位の累積は弾性域で収束しないもの とする。各部材の $\varepsilon_{y i}$ の值は同一とし $\varepsilon_{y}$ とする。

$C_{1}^{j} \cdot w+C_{2}^{j} \cdot \delta_{h} / \ell+C_{3}^{j} \cdot \delta_{v} / \ell+C_{4}^{j}<0:$ 発散

$(j=1,2) \quad \geq 0$ : 収束

$\mathrm{j}=1$ のとき $\delta_{h}=\delta_{h t}$

$\mathrm{j}=2 \quad \prime \delta_{h}=-\delta_{h r}$

$C_{1}^{\mathrm{l}}=-\left(A_{1}+A_{4}+\dot{A}_{5}\right)-A_{2} \cdot \sin \theta_{2}-A_{3} \cdot \sin \theta_{3}$

$C_{2}^{1}=\left(A_{2} \cdot \mu_{2} \cdot \cos \theta_{2} \cdot \sin ^{2} \theta_{2}+A_{3} \cdot \mu_{1} \cdot \cos \theta_{3} \cdot \sin ^{2} \theta_{3}\right) / \varepsilon_{y}$

$C_{3}^{1}=\mu_{3} \cdot\left(A_{1}+A_{2}+A_{5}\right) / \varepsilon_{y}+\left(\dot{A}_{2} \cdot \mu_{2} \cdot \sin ^{3} \dot{\theta}_{2}\right.$

$\left.+A_{3} \cdot \mu_{1} \cdot \sin ^{3} \theta_{3}\right) / \varepsilon_{y}$

$C_{4}^{1}=\left(A_{1}+A_{4}+A_{5}\right) \cdot\left(\mu_{3}-1\right)+A_{2} \cdot \sin \theta_{2}$

$\left(\bar{s}_{2}-\mu_{2} \cdot \bar{e}_{2}\right)+A_{3} \cdot \sin \theta_{3} \cdot\left(\bar{s}_{1}-\mu_{1} \cdot \bar{e}_{1}\right)$

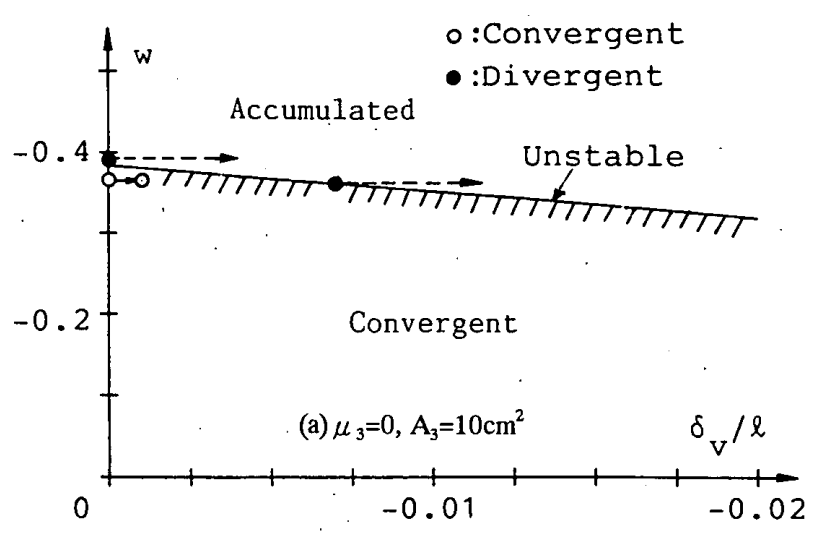

$C_{i}^{2}(\mathrm{i}=1 \sim 4)$ は、 $C_{i}^{1}$ の式の中の $\bar{s}_{n} 、 \bar{e}_{n} 、 \mu_{n}(. \mathrm{n}=1,2)$ を $\bar{s}_{m}, \bar{e}_{m} ， \mu_{\mathrm{m}}$ に置き換えることにより得ることができる ( $\mathrm{n}=1$ のとき $\mathrm{m}=2, \mathrm{n}=2$ のとき $\mathrm{m}=1)$ 。

ここに $\bar{s}_{1}, \quad \bar{e}_{1}, \quad \bar{s}_{2}, \bar{e}_{2}=$ 図-14(a)に示す、ブレースの無 次元降伏応力度及びひずみ度

$\mu_{1} 、 \mu_{2}=$ 図-14(a)に示すブレースの応力度ーひずみ度 関係の塑性域の勾配

$\mu_{3}=$ 図-14(b)に示す柱の応力度一ひずみ度関係の塑性 域の勾配

(4)式を用いて、累積の収束限界時の鉊直力として定 義される収束限界鉛直力を計算により得ることができ る。計算に用いたパラメータは以下の通りである。

$\left\{A_{i}\right\}=\{5,10,10,5,5\},\{5,10,15,5,5\} \quad\left(\mathrm{cm}^{2}\right)$

$\left\{\theta_{i}\right\}=\{90,135,45,90,90\} \quad$ (度)

$\left\{\sigma_{y i}\right\}=\{2.4, ", ",, ", "\} \quad,\left(\mathrm{t} / \mathrm{cm}^{2}\right)$

$\left\{\varepsilon_{y i}\right\}=\{0.11, ", ", ", "\} \quad,(\%)$

$\mu_{1}=0.02 、 \mu_{2}=-0.0 .5 、 \bar{s}_{1}=1 、 \bar{e}_{1}=1 、 \bar{s}_{2}=$. $1, \bar{e}_{2}=-1 、 \delta_{h r} / \ell=0.02$

1) $\mu_{3}=0 、 A_{3}=10 \mathrm{~cm}^{2}$

2) $\mu_{3}=0.02 、 A_{3}=15 \mathrm{~cm}^{2}$

また $W ， \delta_{h} / \ell を 与 え （ 2 ） 、 （ 3 ）$ 式を用いて反復 法による数値計算により逐次 $\mathrm{h}, \delta, / \ell$ を求め、得られ た変形の累積挙動と収束限界鉊直力曲線との比較・検討 を行った。

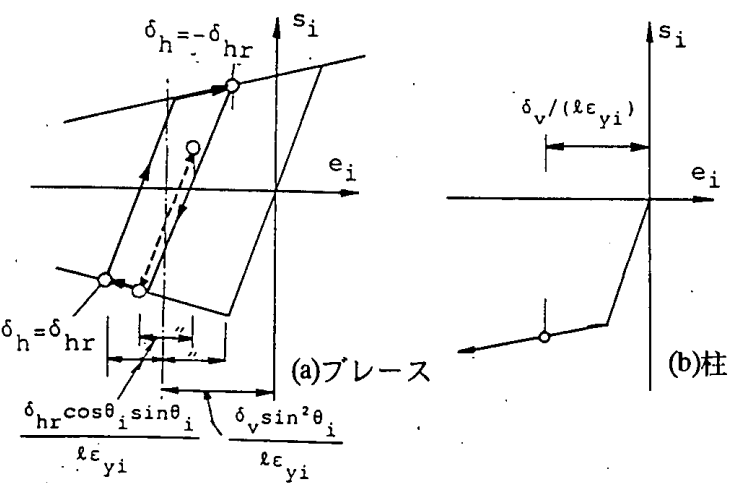

図-15 曲率反転点における応力状態

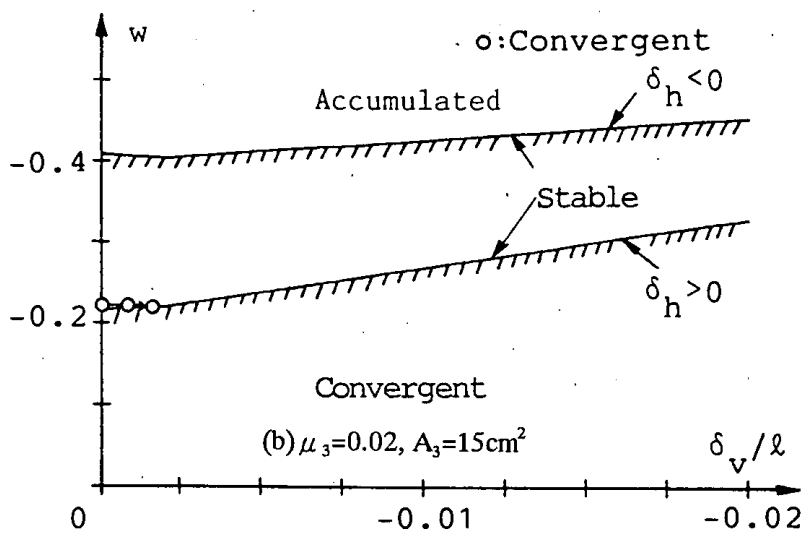

园-16 収束限界鉊直力曲線 
理論計算により得られた収束限界鉊直力曲線である $w-\delta 、 / \ell$ 関係を実線の曲線で図-16に示す。図-16(b)に は、部材番号 $2 、 3$ のブレース断面が異なる場合の $\delta_{b}$ $>0 、 \delta_{n}<0$ における曲線を示すか、このとき収束限 界鈶直力曲線は提案した定理 ${ }^{16) ~ 18)}$ に基づき、 $W$ の值が 小さい $\delta_{b}>0$ の曲線となる。

（4）式で表される収束限界鉛直力曲線の勾配が正の とき、Wが一定值の下では鉊直変位の累積は必ず収束し 構造は安定である。しかし、勾配が負のときは、変位の 累積がConvergentと記された領域を越えた領域で生じる 亡構造は不安定となり、変位の累積は発散する。収束限 界鉊直力曲線の勾配 $C_{3}^{j} / C_{1}^{j}$ の符号は、 $C_{1}^{j}$ の符号が本計 算例では常に負であるから、 $C_{3}^{j}$ の符号で決まる。 $C_{3}^{j}$ の 符号が正のとき $C_{3}^{j} / C_{1}^{j}$ の符号は負となり、曲線の勾配 の符号は正となって変位の累積は必ず収束するが、 $C_{3}^{j}$ の符号が負のときは発散する場合がある。

(4) 式から、最大耐力後の変形の累積を抑え耐力低 下を小さくするためには、収束限界曲線の勾配を正側に 大きくすれば良く、C $C_{3}^{j}$ の值を大きくすればよいことが 分かる。そのためには $A_{1} 、 A_{3} 、 A_{4} 、 A_{5} 、 \mu_{1} 、 \mu_{3}$ の值を大きくとり、かつ $A_{2} 、 \mu_{2}$ の值を小さくとれば良 い。しかし安定領域を增大するためには $C_{2}^{j} 、 C_{4}^{j}$ を小さ くする必要があり、このときは $A_{1} 、 A_{2} 、 A_{4} 、 A_{5}$ 、 $\cdot \dot{\mu_{2}} 、 \mu_{3}$ の值を大きくかつ $A_{3} 、 \mu_{1}$ の值を小さくとれ ばよい。従って、安定領域を大きくしてかつ耐力低下量 を小さくするためには、正縮材の最大耐力、塑性域の勾 配を大きくするとともに、引張り力加力時及び圧縮力加 力時の耐力のバランスを考虑して、ブレースの断面を決 定する必要がある。

図-16には、数值計算から得られた床板の鉛直方向変 位の累積挙動を破線で示す。図中、○及び○は、各々変 形の累積が収束及び発散することを表している。理論計 算から得られた収束限界と数值計算から得られた弾塑性 挙動は良く対応していることが分かる。 $\mu_{3}>0$ のき、 収束限界鉛直力曲線は正勾配であり、構造物の耐力低下 や変位の累積は収束し易い（図16(b)参照)。なおここて は両端ピンの部材からなる単純な構造物のモデルを取り 上げたが、一般のトラス構造物についても同様の結果が 得られた17)。

\section{5 骨組の累積損傷抑制設計}

次に図-17に示す骨組を例にとり、骨組の収束限界外 力及び崩壊限界外力が大きくなるように、適切な構造特 性をもつ部材の構造設計について考えてみる。『一定外 力に主に抵抗する部分の耐力を大きくして耐力低下が生 じない』様に設計すれば良いが、この例では、はりは一 定鈶直力により生じる曲げを負担し柱は一定軸力を負担 している。従ってはり及び柱がともに一定外力を負担し ているので一概に累積損傷を抑制する設計法を述べるこ
とは難しく、骨組全体の収束限界外力曲線に基づき一定 鉛直力比を制限する必要がある。ただし、骨組全体の収 束限界外力及び崩壊限界外力の計算が困難であるとき は、柱及びはりを取り出して、柱は軸力一定の条件、は りは鉛直力一定の条件の下で収束限界外力及び崩壊限界 外力が大きくなるように柱及びはり部材を設計すれば良 いと考えられる。文献20）では、繰返し水平力及びはり に一定鉛直力を受ける骨租の塑性ヒンジ解析を行ない、 収束限界鉊直力は、骨組のはりを単純ばりと仮定したと き、はりの鉊直力載荷点に塑性ヒンジを形成してはりが 崩壊するときの一定鉊直力であることを示しており、骨 組の収束限界時の一定鉊直力を比較的簡単に予测できる ことを提示している。なお本論文で提案した累積損傷を 抑制するための設計法は、構造材料を適材適所に用いる 合成構造及び混合構造に適していると考えられる。

3.6 構造特性の制御による設計

収束限界外力及び崩壊限界外力が大きくなるように適 切な荷重一変形関係、応力度一ひずみ度関係を有する部 材及び断面を選択することにより、変形の累積を抑える ことができる。図-7のモテルが圧縮力を受けていると き、図-18の応力度ーひずみ度関係において引張り側の 降伏応力 $\alpha$ の值は小さく、 $\mu_{t}$ の值が大きい程また $\mu_{\text {。 }}$ （<0）の大きさが小さい程、耐力低下及び変形の累皘 は小さく、累積は早く収束する ${ }^{13)}$ 。しかしこのとき、最 大耐力は小さくなるので、最大耐力の大きさと耐力低下 の大きさのバランスを考慮して、適切な $\mu_{t} 、 \mu_{\text {c 及び } \alpha}$ の設定が必要である。もし累積損傷が小さくなるよう に、荷重一変形関係における引張り側降伏耐力 $\alpha$ 及び引 張り側塑性域剛性 $\mu$, の值が調整されたスライダーが製 作可能であれば、図-19(a),(b)に示す構造の累積損伤は 小さいであろう。図-19(b)に示す骨組では、図-19(a)の はりと同様、繰返し水平力を受けて圧縮側柱の塑性化が 生じると、鈶直力を支持するため骨組の柱の鉛直方向変 形の累皘が生じる。しかしスライダーを用いて引張り側 柱の引張り力を制御することにより、鉛直方向変形の累 積を制御できると考えられる。また所定の荷重一変位関 係を持つように機械的に調整されたヒンジ（メカニカル ヒンジと呼称する）が製作可能であれば、自由に累皘損
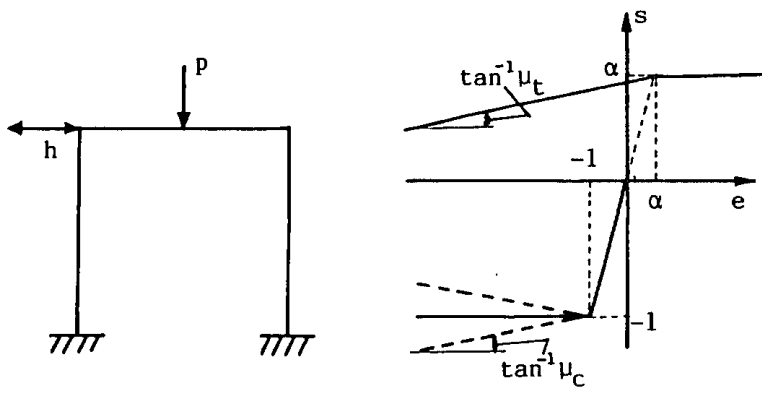

因-17 骨組の累積損傷抑制設計 
傷を制御することが可能である。図-19(c),(d)は、メカ ニカルヒンジを取り付けた構造の一例である。

\section{4. 初期外力による変形累皘の制御及び変形累皘収 束時の破脿の制御}

4.1 初期張力の導入による累積損鹪抑制

耐力低下及び变形累積を抑制する方法として、2.に おいて示したように初期外力を導入する方法も挙げられ る。一定外力及び繰り返し外力を受ける構造物の収束限 界外力曲線が与えられたとき一定外力が $p$ 。゙あれば （図-20(a)参照）、これは収束限界外力曲線の最大值を 超えているので構造物の変形累積は発散する。しかしこ のとき、図-20(b)に一例として示す方法などにより初期 張力 $p_{t}$ を導入することにより、変形累積を収束させる ことができ、また一定外力 $p_{0}$ 。収束限界外力曲線から 必要亡される初期張力の大きさを決定できる。

\section{2 亀裂発生の抑制}

耐力低下及び変形累積の問題と関連して、鋼構造では 2.で挙げた渑裂発生の問題がある。一例として図-21に 一定軸力と定曲率振幅繰返し曲げを受ける角形鋼管柱の 収束限界軸力曲線の模式図を示す。一定軸力が $p$ 。の き、破線で表される重心ひずみの累積が収束限界軸力曲 線に近つくとき、」印の筫所で局部座屈発生部分に刍裂 が発生する ${ }^{14)}$ 。ただし繰返し変位の振幅の大きさが疲労 限度より小さいとき亀裂は発生しないことが予想される が、通常の低サイクル疲労の問題では、疲労限度を超え た変位振幅を問題にするので、変形の累積が収束に向か い繰返し回数が多くなると軙裂は発生すると考えられ る。

塑性域における繰返し加力により入力されるエネル ギーは、変形の累積が進行中では微視的にみると結晶等 の材料構成要素の内部に蓄積されるが、変形の累積が収 束に向かい蓄積エネルギーがある值に達したとき破断が 生じると考えられる。この破断現象は鋼材では亀裂と なって現れ、鉄筋コンクリート部材ではせん断補強筋の 破断 ${ }^{8)}$ となり出現すると予想される。図-21において一 定軸力の值が、収束限界軸力曲線より若干大きい軸力 $p$ 。になるように設計すれば、又は収束限界軸力曲線の位 置を下げるように設計すれば、変形の累積は収束しない が累積の割合は小さくかつ亀裂の発生を防ぐことができ る。

\section{5. 結諭}

一定外力及び繰り返し外力を受ける構造物及び部材の 耐力低下並びに変形の累積を抑制する設計法を、設計例 とともに提案し、筆者らが行った既往の研究結果及び計 算例に基ついて、その設計法の妥当性について検討し た。得られた結論は以下の通りである。
（1）累積損傷を抑制する設計法として、収束限界外力 曲線及び崩壊限界外力曲線に基づき従来の設計手順に一 定外力比制限の判定を組み込む方法が提案できる。

（2）累積損傷を抑制するための設計事項として次の事 項が挙げられる。

1 ）収束限界外力が大きくなるように、部材要素の配 置及び力学特性を選択する。

2 ）初期外力の導入

3）変形累積収束時の破壊抑制のための一定外力比の 設定

（3）『一定外力に主に抵抗する部分と主に繰返し外力 に抵抗する部分を分離して設計する』ことが累積損偤抑 (a)

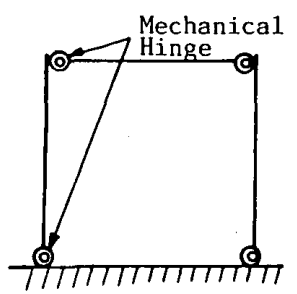

(c)

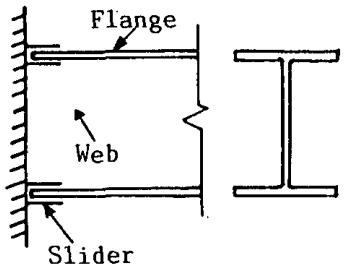

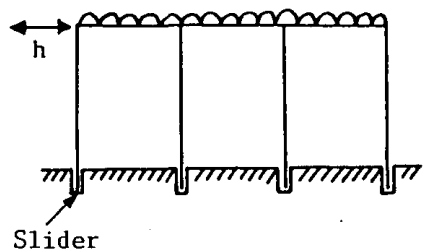

(b)
図-19 構造特性を制御した設計例

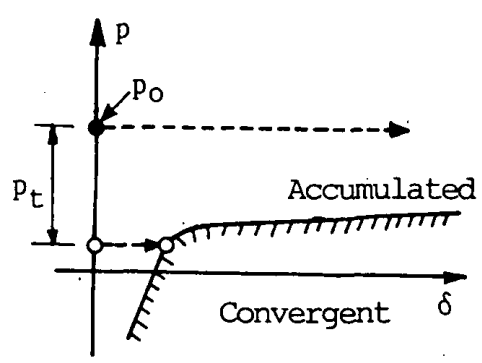

(a)

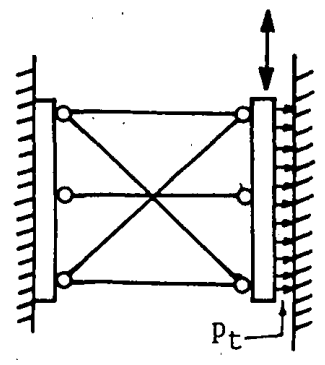

(b)
因-20 初期張力の導入による累積損賃抑制設計

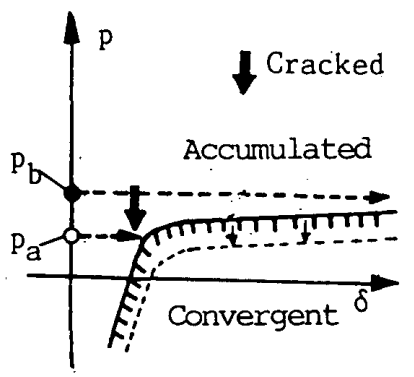

図-21 龟裂発生を抑制する設計 
制に有効である。

今後さらに引き続いて、累積損傷を抑制するための設 計法及び設計例の妥当性を実験及び解析により確かめて いく予定である。

\section{参考文献}

1）高梨晃一、田中尚、宇田川邦明、笠井政之：軸力と繰返し 曲げを受ける $\mathrm{H}$ 形鋼柱の変形能力、日本建築学会大会学術講 演梗概集、pp.1081 1082、昭和51年10月

2）宇田川邦明、高梨晃一、田中尚：繰り返し載荷を受ける H 形鋼はりの復元力特性（その1）定変位振幅繰り返し載荷時の 塑性ヒンジ回転能力、（その2）ランダム変位履歴における耐 力の低下、日本建築学会論文報告集、第264号、pp.51 59、 1978年2月、第265号、pp.45 52、1978年3月

3）上谷宏二、中村恒善、常岡次郎：繰り返し両振り曲げを受 ける片持ち梁一柱の構面外变形発生機構之限界点理論、日本 建築学会大会学術講演梗概集、pp.1077 1078、昭和63年10 月

4) Uetani, K. and T. Nakamura: Symmetry Limit Theory for Cantilever Beam-Columns Subjected to Cyclic Reversed Bending, J. Mech. Phys. Solids, Vol.31, pp.449 484, 1983

5）近藤一夫、花井正実: 繰り返し変動荷重を受ける構造物の 弾塑性解析、日本建築学会構造系論文報告集、第364号、 pp.33 43、昭和61年6月

6) 近藤一夫、王学鋒、中倉健介、花井正実 : 繰り返し変動曲 げを受ける鋼柱の弾塑性・崩壊挙動、日本建築学会構造系論 文報告集、第434号、pp.59 74、平成4年4月

7) 松井千秋、津田恵吾、江冠華：一定軸力之綝り返し曲げを 受けるS R C 断面および柱材の曲げ挙動について（その1）、 （その2）、日本建築学会九州支部研究報告、第31号、pp.341 ～348、平成元年 3 月

8）平石久度、稲井栄一、板倉康久、高崎哲哉、石渡康弘、川 島俊一、栜使川原正臣：鉄筋コンクリート造柱の曲げ降伏後 の限界変形に関する研究（その1）柱の中心王縮実験、純曲げ 実験および曲げせん断実験とその相関、日本建築学会構造系 諭文報告集、第410号、pp.27 39、平成2年4月

9）加藤勉、秋山宏：鋼構造剛接骨組の耐震極限設計、日本建 築学会論文報告集、第237号、pp.59 65、昭和50年11月 10）秋山宏、高橋誠：損傷分散型骨組の一般化、日本建築学 会論文報告集、第365号、pp.20 27、1986年7月

11）山田稳、河村広：銅構造物の耐震安全について（1）、 （3）、日本建築学会論文報告集、第227号、pp.67 74、 1975年1月、278号、pp.55 66、1979年 4 月

12) Uchida, Y. and S. Morino:Biaxial Bending Moment-Curvature Relation of Box Beam-Column with Degrading StressStrain Relation, Research Reports of the Faculty of Eng., Mie University,Vol.11, pp.55 67,Dec. 1986

13）内田保博、森野捷戟 : Limit of Axial Force Ratio for De- grading Steel Beam-Columns Involving Local Buckling,日本建 築学会構造系論文報告集、第425号、pp.57 68、平成 3 年 7 月

14）内田保博、三谷動、上遠野明夫、小御門匡 : 角形鋼管柱 の軸力比制限に関する実験的研究, ,日本建築学会構造系論文 報告集、第454号、pp.139 149、平成5年12月

15）内田保博：繰返し外力を受ける構造物および部材の変形 累積に関する法則、鹿児島大学工学部研究報告、第33号、 pp.167 177、平成 3 年 9 月

16）内田保博：複数の一定外力及び繰り返し曲げを受け耐力 低下を生じる角形鋼管柱の一定外力制限、日本建築学会九州 支部研究報告、第33号、pp.285 288、平成 4 年 3 月

17）内田保博、小御門匡：繰返し外力を受けるトラス構造の 耐力低下及び変形累積挙動に関する研究、日本建築学会棈造 系論文報告集、第454号、pp.161 170、平成5年12月

18）内田保博：軸力及び繰返し曲げを受け耐力低下を生じる 柱の変形累積の安定性、日本建築学会構造系論文報告集、第 448号、pp. 131 140、平成5年6月

19）内田保博：2次仕事に基つく構造に生じる変形累積の安定 性解析、日本建築学会構造系諭文報告集、第454号、pp.151 159、平成5年 12 月

20）内田保博、肥山正宏：一定鉛直力及び繰返し水平力を受 ける骨組及び耐力壁の累積損傷に関する研究、日本建築学会 九州支部研究報告、第34号・1、pp. 377 380、1994年3月 21）内田保博：繰り返し外力を受ける構造物の累積損甥抑制 設計、棈造工学論文集、Vol.39B、pp. 619～631、1993年3月 (1994 年 4 月 4 日原稿受理, 1994 年 10月 14 日採用决定) 